\title{
The degradation of different protein supplements in the rumen of steers and the effects of these supplements on carbohydrate digestion
}

\author{
By A. B. MCALLAN, J. E. COCKBURN, A. P. WILLIAMS \\ AND R. H. SMITH*
AFRC Institute for Grassland and Animal Production, Animal and Grassland Research Station, Hurley, Maidenhead, Berkshire SL6 5LR†

(Received 23 November 1987 - Accepted 25 July 1988)

\begin{abstract}
1. Four steers with simple rumen and abomasal cannulas were given diets consisting of ground and pelleted alkali-treated straw, rolled barley and tapioca supplemented with urea (diet $U$ ) or containing single-cell protein (diet SCP), maize-gluten meal (diet MGM) or rapeseed meal (diet RSM) in place of some of the tapioca. The isoenergetic diets were given in a $4 \times 4$ Latin square design in eight feeds/d at 3 -h intervals and provided sufficient metabolizable energy to support a growth rate of approximately $0.5 \mathrm{~kg} / \mathrm{d}$. Chromic oxide and polyethylene glycol were given as markers and appropriate samples taken from the rumen and abomasum. Flows ( $\mathrm{g} / \mathrm{d}$ ) at the abomasum of organic matter and nitrogenous and carbohydrate constituents were calculated.

2. Rumen ammonia levels were similar with all three protein supplements at about $9 \mathrm{mmol} / 1$, which was significantly lower $(P<0.05)$ than that in animals on diet $\mathrm{U}(16 \mathrm{mmol} / \mathrm{l})$. Rumen liquid outflow rates $(/ \mathrm{h})$ were $0.099,0.139,0.125$ and 0.160 for diets U, SCP, MGM and RSM respectively; the difference between diet U and diet RSM was significant $(P<0.05)$. Corresponding values for $\mathrm{Cr}_{2} \mathrm{O}_{3}$ outflow rates were $0.027,0.032,0.027$ and $0 \cdot 030 / \mathrm{h}$ respectively, which did not differ significantly from each other.

3. RNA, ${ }^{35} \mathrm{~S}$ and diaminopimelic acid (DAP) were used as microbial markers. Efficiencies of microbial-N (MN) synthesis, expressed as $\mathrm{g} \mathrm{MN} / \mathrm{kg}$ apparently digestible organic matter, truly digestible organic matter or carbohydrate fermented, were generally not significantly affected by the diet and averaged 29,22 and 29 respectively based on mean RNA and ${ }^{35} \mathrm{~S}$ markers. Corresponding values derived from DAP of 22,16 and $21 \mathrm{~g}$ $\mathrm{MN} / \mathrm{kg}$ respectively were all significantly $(P<0 \cdot 001)$ lower. Using ${ }^{35} \mathrm{~S}$ as microbial marker, MN flows at the abomasum as a proportion of non-ammonia-nitrogen flow were $0.78,0.64,0.51$ and 0.78 for diets $\mathrm{U}, \mathrm{SCP}, \mathrm{MGM}$ and RSM respectively. Derived true rumen degradability values ( $\mathrm{g} / \mathrm{g}$ intake) of the total dietary $\mathrm{N}$ were $0.91,0.79$, 0.69 and 0.90 for diets U, SCP, MGM and RSM respectively. Protein supplement degradabilities for single-cell protein, maize-gluten meal and rapeseed meal were $0.73,0.51$ and 0.98 respectively.

4. Mouth-to-abomasum digestibility coefficients of the main neutral-sugar components of dietary polysaccharides were $0.68,0.63$ and 0.61 for arabinose, xylose and cellulose-glucose on diet $U$. These values were generally significantly increased with protein supplementation, but to different extents depending on the source. Maximum digestibility values of 0.81, 0.79 and 0.76 were obtained for arabinose, xylose and cellulose-glucose with diet RSM. Starch-glucose digestibility was high $(0 \cdot 90)$ on all diets and unaffected by supplementation.
\end{abstract}

Protein-rationing systems for ruminants have been put forward in a number of countries over recent years (Kaufmann, 1977; Verite et al. 1979; Agricultural Research Council, 1980 , 1984; Madsen, 1985). Of prime importance in all these systems is the need to predict microbial protein synthesis and the extent of degradation of feed protein with different diets. Part of the purpose of the present study was to examine how these factors varied when diets based on proteins of widely different kinds were used. However, another matter of great importance is the influence of dietary nitrogen on carbohydrate digestion in the rumen. There is evidence that not only the amount of available $\mathrm{N}$ but also the form of the $\mathrm{N}$ influences carbohydrate and particularly fibre digestion in the rumen (McAllan \& Smith, $1983 b$; McAllan \& Griffith, 1987).

The present experiments were undertaken to determine the in vivo degradability of three markedly different proteins (with respect to nature, solubility, etc.) derived using different microbial markers and to study the effects of those proteins on the digestion of dietary carbohydrates.

* Honorary Research Associate.

† Incorporating AFRC Institute for Grassland and Animal Production, Hurley and the National Institute for Research in Dairying, Shinfield. 


\section{METHODS \\ Animals, diets and collection of digesta}

The experiment was designed as a $4 \times 4$ Latin square. Four Friesian steers were used, each fitted with simple rumen and abomasal cannulas at approximately 13-15 weeks of age as described by Smith \& McAllan (1970). Approximately 10-12 weeks were allowed for recovery from surgery, and at the beginning and end of the experiment respectively the animals had mean weights (kg) of 142 (SE 2.8) and 190 (SE 2.5) and mean ages (weeks) of $25 \cdot 2$ (SE 0.6 ) and $38 \cdot 0$ (SE 0.6).

The animals were given four isoenergetic diets calculated to support a growth rate of approximately $0.5 \mathrm{~kg} / \mathrm{d}$ (Ministry of Agriculture, Fisheries and Food, 1975). The diets consisted of approximately equal portions of ground and pelleted alkali-treated straw (Viton; BOCM Silcock Ltd, Basingstoke) and a concentrate mixture of rolled barley and tapioca. One diet was supplemented with urea and casein (diet $U$ ) and the other three diets had part of the tapioca replaced with a single-cell protein isolate (diet SCP), maize-gluten meal (CPC, Manchester; diet MGM) or Canadian rapeseed meal (Tower, 00; J. Bibby Agriculture Ltd, Fromingham; diet RSM). Details of the diets and intakes are given in Table 1 . All diets contained a mineral-vitamin supplement. The straw and barley provided about $38 \%$ of the total- $\mathrm{N}$ on all diets. Urea contributed $49 \%$ of total-N intake for diet $\mathrm{U}$ and $10 \%$ for the other diets. The protein supplements all supplied $60 \%$ of the total-N intakes of their respective diets. Diets were given in eight equal portions at three-hourly intervals by automatic feeding devices.

Each experimental period lasted for $20 \mathrm{~d}$ (except for period 1 where, for technical reasons, the period lasted $30 \mathrm{~d}$ ) at the end of which time the diets were changed. In each period from day 7 (day 17, period 1), $25 \mathrm{ml}$ of a solution containing $7.2 \mathrm{~g}$ polyethylene glycol (molecular weight $4000 ; \mathrm{PEG}$ ), $61.5 \mu \mathrm{Ci}^{35} \mathrm{~S}$ and $115 \mathrm{mg}$ sodium sulphate was added to each of the eight equal portions of feed daily. Paper impregnated with chromic oxide was also mixed in with the diet at a rate of approximately $1.8 \mathrm{~g} \mathrm{Cr}_{2} \mathrm{O}_{3} / \mathrm{kg}$ dry matter (DM). On day 13 (day 23, period 1) samples (approximately $300 \mathrm{~g}$ ) of abomasal digesta were taken immediately before and after a feed and mid-way between two feeds. Individual samples were homogenized, combined on an equal weight basis, homogenized once again and stored for subsequent analysis. On day 15 (day 25, period 1) samples of rumen digesta (approximately $400 \mathrm{~g}$ ) were taken immediately before and after a feed and mid-way between two feeds and combined. Samples of mixed rumen protozoa and mixed rumen bacteria were separated as described by Cockburn \& Williams (1984) and Smith \& McAllan (1974) respectively. A subsample of the isolated bacterial and protozoal fractions (about $25 \mathrm{~g}$ ) was removed and extracted immediately for RNA estimation (McAllan \& Smith, 1969) and the remainder stored for subsequent analysis. From day 16 (day 26, period 1) marker additions (PEG, ${ }^{35} \mathrm{~S}$ and $\mathrm{Cr}_{2} \mathrm{O}_{3}$ ) were stopped and small rumen samples (approximately $50 \mathrm{ml}$ ) were taken at frequent intervals over the following $72 \mathrm{~h}$ and stored for the estimation of marker disappearance rate. Throughout each experimental period small samples of rumen digesta were taken every 2 or $3 \mathrm{~d}$ and ciliate protozoa numbers were estimated according to Warner (1962).

In each period samples of rumen digesta (about $400 \mathrm{~g}$ ) were taken from one steer at the start of the marker infusion about $1.5 \mathrm{~h}$ after a feed and then daily at the same time for the $7 \mathrm{~d}$ of ${ }^{35} \mathrm{~S}$ feeding. Rumen bacteria were separated as described previously and used to confirm establishment of equilibration of ${ }^{35} \mathrm{~S}$ uptake. On other days (days 16-18), small samples of rumen digesta were removed just before a feed and $0.5,1.5$ and $2.5 \mathrm{~h}$ after a feed. $\mathrm{pH}$ was measured immediately and the sample was then acidified and used to determine ammonia concentrations. 
Table 1. Amounts of the main dietary components ( $\mathrm{kg}$ dry matter/d), nitrogen $(\mathrm{g} / \mathrm{d})$ and metabolizable energy $(M E, M J / d)$ given to steers weighing $135-149 \mathrm{~kg}^{*}$

\begin{tabular}{|c|c|c|c|c|}
\hline $\begin{array}{l}\text { Diet ... } \\
\text { Component }\end{array}$ & $\mathrm{U}$ & SCP & MGM & RSM \\
\hline Alkali-treated straw pellets & $1 \cdot 17$ & $1 \cdot 17$ & $1 \cdot 17$ & $1 \cdot 17$ \\
\hline Rolled barley & 1.01 & 1.01 & 1.01 & 1.01 \\
\hline Tapioca & 0.39 & $0 \cdot 10$ & 0.14 & - \\
\hline Maize-gluten meal & - & - & 0.32 & - \\
\hline Single-cell protein & - & 0.30 & - & - \\
\hline Rapeseed meal & - & - & - & 0.56 \\
\hline Urea & 0.074 & 0.015 & 0.015 & 0.015 \\
\hline Casein & 0.058 & 0.034 & 0.034 & 0.034 \\
\hline Nitrogen & $70 \cdot 8$ & $74 \cdot 2$ & $74 \cdot 2$ & 74.6 \\
\hline $\begin{array}{l}\text { Estimated } \dagger \text { rumen-degradable } \\
\mathrm{N}(\mathrm{RDN})\end{array}$ & $64 \cdot 1$ & $58 \cdot 3$ & 52.5 & 66.8 \\
\hline $\mathrm{ME}_{\ddagger}^{+}$ & $28 \cdot 8$ & $29 \cdot 1$ & $28 \cdot 7$ & $30 \cdot 9$ \\
\hline RDN:ME & $2 \cdot 23$ & $2 \cdot 00$ & 1.83 & $2 \cdot 16$ \\
\hline
\end{tabular}

* These amounts were increased by $5 \%$ for each succeeding $15 \mathrm{~kg}$ weight range.

† Estimated from degradabilities obtained in the present experiment by using ${ }^{35} \mathrm{~S}$ (see Table 4).

$\$$ Calculated from energy values $(\mathrm{MJ} / \mathrm{kg}$ ) for individual components of : alkali-treated straw $7 \cdot 3$, rolled barley $12 \cdot 9$, tapioca $15 \cdot 0$, casein $15 \cdot 0$, maize-gluten meal $15 \cdot 0$, single-cell protein $15 \cdot 1$, rapeseed meal $10 \cdot 9$.

\section{Analytical and calculations}

$\mathrm{DM}$, organic matter (OM) and $\alpha-\varepsilon$-diaminopimelic acid (DAP) were determined as described by Smith et al. (1978). Total-N (TN) and ammonia-N were estimated by the procedures of Smith \& McAllan (1970) and Merry (1980) respectively. Urea-N was estimated colorimetrically by the procedure of Technicon Instruments Corporation (1967). $\mathrm{Cr}_{2} \mathrm{O}_{3}$ was determined according to Williams \& Smith (1974) and PEG by the method of Smith \& McAllan (1971). Monosaccharide components of feedstuffs, bacteria and digesta samples were analysed as described by McAllan \& Smith (1974). RNA was estimated as described by McAllan \& Smith (1969) and ${ }^{35} \mathrm{~S}$ by the method of Mathers \& Miller (1980).

Daily flows of digesta constituents were calculated using the dual-phase-marker procedure of McAllan \& Smith $(1983 b)$; average $\mathrm{Cr}_{2} \mathrm{O}_{3}$ :PEG values in abomasal digesta were 0.195 (SE 0.0127) ( $n$ 16) which were 1.187 (SE 0.067) ( $n 16)$ of the ratios in the feeds. Marker $\left({ }^{35} \mathrm{~S}\right.$, RNA and DAP): $\mathrm{N}$ values were established in microbial samples from each steer on each diet and the proportion of non- $\mathrm{NH}_{3}-\mathrm{N}$ (NAN) in abomasal digesta which was of microbial origin was estimated according to McAllan \& Smith (1983a). Apparently digested organic matter (ADOM) was measured as the difference between OM intake and OM flow at the abomasum $(\mathrm{g} / \mathrm{d})$. Truly digested organic matter (TDOM) was measured as ADOM + microbial organic matter (MOM) flow. MOM flow was estimated as:

MOM flow at abomasum $=\frac{\mathrm{OM}}{\mathrm{N}}$ (bacterial isolates $) \times \mathrm{MN}$ flow at the abomasum,

$\mathrm{OM}: \mathrm{N}$ ratios were established in bacterial isolates from each steer on each diet, $\mathrm{MN}$ is microbial-N.

Degradability of protein in total diets was estimated as:

Total NAN flow-MN flow + endogenous-N (EN) flow, total NAN intake 
Table 2. Mean ciliate protozoa numbers, ammonia-nitrogen concentration (mmol/l) and $p H$ values in rumen digesta from steers receiving diets containing different protein supplements*, together with fractional outflow rates of polyethylene glycol (PEG) and chromic oxide from the rumen over 24 and $48 \mathrm{~h}$ respectively. Also shown are ${ }^{35} S: N$ values (disintegrations/min ( $\mathrm{dpm}$ ) per $\mathrm{mg} N$ ) in samples of mixed bacteria and mixed protozoa isolated from rumen digesta taken $9 d$ after the start of infusion of ${ }^{35} S$ into the rumen

(Results are mean values with their standard errors for four steers unless otherwise stated)

\begin{tabular}{|c|c|c|c|c|c|c|c|c|}
\hline \multirow{2}{*}{ Diet... } & \multicolumn{2}{|c|}{$\mathrm{U}$} & \multicolumn{2}{|c|}{ SCP } & \multicolumn{2}{|c|}{ MGM } & \multicolumn{2}{|c|}{ RSM } \\
\hline & Mean & SE & Mean & $\mathrm{SE}$ & Mean & $\mathrm{SE}$ & Mean & $\mathrm{SE}$ \\
\hline Protozoa $\left(\times 10^{5} / \mathrm{ml}\right) \ddagger$ & $16 \cdot 4$ & 1.03 & $18 \cdot 4$ & 1.47 & $16 \cdot 2$ & 1.42 & $16 \cdot 3$ & $3 \cdot 18$ \\
\hline $\mathrm{NH}_{3}-\mathrm{N}(\mathrm{mmol} / \mathrm{l})$ & $16 \cdot 4$ & $2 \cdot 57$ & $9 \cdot 2$ & $1 \cdot 46$ & 10.6 & $2 \cdot 42$ & $8 \cdot 0$ & 0.95 \\
\hline $\mathrm{pH}$ & $6 \cdot 58$ & 0.035 & $6 \cdot 40$ & 0.036 & $6 \cdot 40$ & $0 \cdot 045$ & $6 \cdot 57$ & 0.057 \\
\hline Fractional outflow $(/ \mathrm{h}):$ PEG & $0 \cdot 10$ & 0.018 & 0.14 & 0.030 & $0 \cdot 13$ & 0.034 & $0 \cdot 16$ & 0.019 \\
\hline $\mathrm{Cr}_{2} \mathrm{O}_{3}$ & 0.03 & 0.002 & 0.03 & $0-003$ & $0 \cdot 03$ & 0.005 & 0.03 & 0.004 \\
\hline${ }^{35} \mathrm{~S}: \mathrm{N}(\mathrm{dpm} / \mathrm{mg})\left(\times 10^{-3}\right):$ Bacteria & $8 \cdot 8$ & 0.52 & 6.6 & $0 \cdot 32$ & $6 \cdot 8$ & $0 \cdot 30$ & $4 \cdot 5$ & 0.50 \\
\hline Protozoa & $10 \cdot 7$ & $0 \cdot 35$ & $6 \cdot 4$ & $0 \cdot 49$ & $5 \cdot 7$ & 0.99 & $4 \cdot 5$ & 0.41 \\
\hline
\end{tabular}

U, Straw + barley + urea + casein; SCP, straw + barley + urea + casein + single-cell protein; $M$, straw + barley + urea + casein + maize-gluten meal; RSM, straw + barley + urea + casein + rapeseed meal.

* For details, see Table 1.

$\dagger$ Only three values.

where an EN flow of $0.032 \mathrm{~g} / \mathrm{kg}$ live weight per $\mathrm{d}$ was assumed (Ørskov \& MacLeod, 1983).

In estimating the degradability of the individual protein supplements it was assumed that all the casein supplementary protein and urea- $\mathrm{N}$ were degraded in the rumen. Thus surviving feed- $\mathrm{N}$ at the abomasum of steers receiving diet $\mathrm{U}$ was assumed to derive entirely from the straw and rolled barley components ( + BNAN), the degradability of which was calculated as described previously but where the denominator was straw + barley NAN intake. It was then assumed that the straw + barley protein degradability would not be altered in the other diets thus:

supplemented protein degradability $=$

total NAN flow -- $[\mathrm{S}+\mathrm{BNAN}$ intake $\times(1-\mathrm{S}+\mathrm{BNAN}$ degradability $)+\mathrm{MN}$ flow + EN flow $]$ supplement protein NAN intake

The statistical analysis used was standard analysis of variance appropriate to the Latin square design (Cochran \& Cox, 1962) taking account of variation between calves, periods and rations. The significance of differences between ration means was tested using standard errors based on the error squares with $6 \mathrm{df}$. Supplemental protein degradability values which did not fit the Latin square model were compared by paired $t$ test (Snedecor \& Cochran, 1972) as were some comparisons of values between markers.

\section{RESULTS}

\section{Rumen characteristics}

Numbers of ciliate protozoa in rumen digesta remained fairly constant throughout the experiment (Table 2). Numbers in digesta from animals receiving single-cell protein (diet $\mathrm{SCP}$ ) tended to be greater than those receiving the other diets but the difference was not significant. The incorporation of ${ }^{35} \mathrm{~S}$ into rumen bacterial and protozoal protein had 
Table 3. Mean amounts $(\mathrm{g} / \mathrm{d})$ of dietary nitrogen consumed and digesta- $N$ components flow at the abomasum of steers receiving diets containing different protein supplements*

(Results are mean values with their standard errors for four steers)

\begin{tabular}{|c|c|c|c|c|c|c|c|c|}
\hline \multirow[t]{2}{*}{ Diet... } & \multicolumn{2}{|c|}{$\mathrm{U}$} & \multicolumn{2}{|c|}{ SCP } & \multicolumn{2}{|c|}{ MGM } & \multicolumn{2}{|c|}{ RSM } \\
\hline & Mean & $\mathrm{SE}$ & Mean & $\mathrm{SE}$ & Mean & SE & Mean & $\mathrm{SE}$ \\
\hline Total- $\mathrm{N}$ intake $(\mathrm{g} / \mathrm{d})$ & $76 \cdot 2$ & $2 \cdot 45$ & $81 \cdot 0$ & $3 \cdot 1$ & $81 \cdot 8$ & $3 \cdot 17$ & $80 \cdot 9$ & $2 \cdot 89$ \\
\hline \multicolumn{9}{|l|}{ Abomasal flows $(\mathrm{g} / \mathrm{d})$} \\
\hline Ammonia-N & $2 \cdot 26$ & 0.81 & $2 \cdot 50$ & $0 \cdot 34$ & $2 \cdot 56$ & 0.63 & $3 \cdot 00$ & 0.42 \\
\hline Non-ammonia-N & $54 \cdot 8$ & $5 \cdot 0$ & $61 \cdot 8$ & 1.8 & $67 \cdot 5$ & $3 \cdot 4$ & 59.8 & $5 \cdot 2$ \\
\hline RNA-N & 3.87 & $0 \cdot 23$ & $4 \cdot 11$ & 0.40 & $3 \cdot 23$ & $0 \cdot 34$ & $4 \cdot 26$ & 0.53 \\
\hline DAP-N & $0 \cdot 142$ & 0.020 & 0.117 & 0.007 & $0 \cdot 103$ & 0.016 & $0 \cdot 117$ & $0 \cdot 016$ \\
\hline \multirow{3}{*}{$\begin{aligned} \text { Microbial-N: } & \underset{1}{\text { RNA }} \\
& { }^{35} \mathrm{DAP}\end{aligned}$} & $41 \cdot 1$ & $2 \cdot 4$ & $43 \cdot 7$ & $4 \cdot 2$ & $34 \cdot 3$ & $3 \cdot 6$ & $45 \cdot 3$ & 5.6 \\
\hline & $42 \cdot 5$ & $1 \cdot 7$ & $39 \cdot 5$ & $1 \cdot 8$ & $34 \cdot 2$ & $2 \cdot 1$ & $47 \cdot 3$ & $3 \cdot 7$ \\
\hline & 35.9 & $5 \cdot 1$ & $29 \cdot 5$ & $1 \cdot 7$ & $25 \cdot 9$ & $4 \cdot 0$ & $29 \cdot 6$ & $3 \cdot 5$ \\
\hline
\end{tabular}

U, Straw + barley + urea + casein; SCP, straw + barley + urea + casein + single-cell protein ; MGM, straw + barley + urea + casein + maize gluten meal; RSM, straw + barley + urea + casein + rapeseed meal; DAP-N, $\alpha-6$-diaminopimelic acid-N.

* For details, see Table 1.

$\dagger$ Calculated from measured RNA flows 'adjusted' $(\times 0.85)$ to correct for surviving feed RNA (Smith et al. 1978).

reached maximum levels by the fourth day after the start of infusing ${ }^{35} \mathrm{~S}$ with all diets and remained essentially constant over the remainder of the infusion period. Relations (paired $t$ test comparisons) found between ${ }^{35} \mathrm{~S}$ and NAN in mixed rumen bacteria and protozoa showed that significantly $(P<0.05)$ more ${ }^{35} \mathrm{~S}$ was incorporated into both bacteria and protozoa in animals receiving the urea diet (diet $U$ ). Incorporation of ${ }^{35} \mathrm{~S}$ into the microbes of animals receiving diets containing rapeseed meal (diet RSM) tended to be lower than in those animals receiving diets SCP or MGM, but the difference was only significant $(P<$ 0.05 ) between rumen bacteria from animals receiving diet MGM. Mean rumen $\mathrm{pH}$ values are also presented in Table 2 . There was little between-feeding variation within diets (maximum spread $0 \cdot 2$ units) and no significant differences between values obtained with different diets. There was also little between feeding variation in rumen ammonia levels which remained above $5 \mathrm{mmol} / \mathrm{l}$ at all times, but in comparing mean values (Table 2) it was found that levels in rumen digesta from animals receiving diet $\mathbf{U}$ were significantly greater $(P<0.05)$ than in digesta from animals receiving the other diets. PEG and $\mathrm{Cr}_{2} \mathrm{O}_{3}$ rumen outflow rates are also presented in Table 2. There were no significant differences between $\mathrm{Cr}_{2} \mathrm{O}_{3}$ rumen outflow rates on any diet. PEG rumen outflow rates tended to be lower with diet U compared with the other diets but this was only significant $(P<0.05)$ compared with diet RSM.

\section{Nitrogenous constituent flow at the abomasum and feed-protein degradability}

Abomasal flows of various nitrogenous constituents are presented in Table 3 . Urea- $\mathrm{N}$ was not detected in any digesta samples. There were no significant differences between diets on the amounts of $\mathrm{NH}_{3}-\mathrm{N}$ passing the abomasum/d. NAN flows at the abomasum were, on average, about $0.75 \mathrm{~g} / \mathrm{g}$ NAN intake. In paired $t$ test comparisons, amounts of NAN flowing at the abomasum of steers receiving diets SCP, MGM or RSM were greater than for those receiving the diet $\mathrm{U}$. These differences approached significance for diet SCP $(P$ $<0.10)$ and were significant $(P<0.01)$ for diet MGM. RNA-N flows tended to be higher with diets SCP and RSM and lower with diet MGM compared with the basal diet but the 
Table 4. Mean estimates ( $\mathrm{g} / \mathrm{g}$ intake) of total feed-nitrogen, protein-supplement- $N$ and basal-component- $N$ degraded between mouth and abomasum of steers receiving diets containing different protein supplements

(Results are presented for values derived using RNA, ${ }^{35}$ S or DAP as microbial markers)

\begin{tabular}{|c|c|c|c|c|c|c|}
\hline \multirow[t]{2}{*}{ Microbial marker... } & \multicolumn{2}{|c|}{ RNA } & \multicolumn{2}{|c|}{${ }^{35} \mathrm{~S}$} & \multicolumn{2}{|c|}{ DAP } \\
\hline & Mean & $\mathrm{SE}$ & Mean & $\mathrm{SE}$ & Mean & SE \\
\hline \multicolumn{7}{|l|}{ Protein degradability $\dagger$} \\
\hline \multicolumn{7}{|l|}{ Complete feed } \\
\hline Diet U & 0.89 & 0.030 & 0.91 & 0.027 & 0.82 & 0.080 \\
\hline Diet SCP & 0.84 & 0.048 & 0.79 & 0.012 & 0.66 & 0.012 \\
\hline Diet MGM & 0.66 & 0.030 & 0.69 & 0.023 & 0.58 & 0.053 \\
\hline Diet RSM & 0.88 & 0.047 & 0.90 & 0.031 & 0.68 & 0.022 \\
\hline \multicolumn{7}{|l|}{ Protein supplement } \\
\hline Single-cell protein & 0.88 & 0.027 & 0.73 & 0.050 & 0.64 & 0.025 \\
\hline Maize-gluten meal & 0.55 & 0.013 & 0.51 & 0.053 & 0.47 & 0.099 \\
\hline Rapeseed meal & 0.96 & 0.056 & 0.98 & 0.056 & 0.66 & 0.055 \\
\hline $\begin{array}{l}\text { Basal ingredients } \S \\
\text { Straw-barley }\end{array}$ & 0.71 & 0.055 & 0.76 & 0.054 & 0.54 & 0.076 \\
\hline
\end{tabular}

U, Barley + straw + urea + casein; SCP, barley + straw + urea + casein + single-cell protein; MGM, barley + straw + urea + casein + maize-gluten meal; RSM, barley + straw + urea + casein + rapeseed meal; DAP, $\alpha-\epsilon^{-}$ diaminopimelic acid.

* For details, see Table 1.

$\dagger$ Corrected for an assumed endogenous- $\mathrm{N}$ secretion of $0.032 \mathrm{~g} / \mathrm{d}$ per $\mathrm{kg}$ live weight.

\$ Corrected for surviving basal-feed- $\mathrm{N}$ at abomasum derived from each individual marker.

$\S$ Assuming urea and casein are completely degraded in the rumen.

differences were not significant. No significant differences were found in the amounts of DAP-N passing the abomasum/d related to diet. $\mathrm{MN}$ flows calculated using RNA as a microbial marker were not significantly different $(P<0.05)$ between diets. When ${ }^{35} \mathrm{~S}$ was used as microbial marker significantly lower MN flows $(P<0.05)$ were found for diet MGM compared with diets U and RSM, and for diet SCP compared with diet RSM. MN flow as a proportion of NAN flow (based on ${ }^{35} \mathrm{~S}$ ) was $0.53,0.64,0.78$ and 0.78 for diets MGM, SCP, RSM and U respectively. There were no significant differences between MN flows with different diets calculated using DAP as a microbial marker, but these were significantly $(P<0.001)$ lower by about $25 \%$ than flows calculated using either RNA or ${ }^{35} \mathrm{~S}$.

Feed-protein degradability values, between mouth and abomasum are presented in Table 4. Comparisons of total feed- $\mathrm{N}$ degradability within any one marker showed that diet MGM-N was significantly $(P<0.05)$ less degraded than $\mathrm{N}$ in the other three diets. Diet SCP-N degradability was also found to be significantly less $(P<0 \cdot 05)$ compared with diets $\mathrm{U}$ and RSM with both ${ }^{35} \mathrm{~S}$ and DAP as microbial markers but not with RNA. For the individual protein supplement $\mathrm{N}$ degradability (also shown in Table 4) values derived using ${ }^{35} \mathrm{~S}$ for maize-gluten and rapeseed were not significantly different from those derived using RNA. Single-cell-protein-N degradability values derived using RNA however, were significantly $(P<0.05)$ higher than those using ${ }^{35} \mathrm{~S}$. Comparison of $\mathrm{N}$ degradability values obtained using different markers showed that apart from the single-cell-protein supplement, there were no significant differences between results obtained using either ${ }^{35} \mathrm{~S}$ or RNA. However, apart from the value for complete feed- $N$ degradability of diet $U$, all other $N$ degradabilities derived using DAP were significantly lower than the corresponding values derived from either ${ }^{35} \mathrm{~S}$ or RNA. 
Table 5. Mean microbial-nitrogen yields in terms of amounts of organic matter (OM) apparently $(A D O M)$ or truly $(T D O M)$ digested in the rumen or of total carbohydrate digested in the rumen of steers receiving diets containing different protein supplements*

(Results are mean values with their standard errors for four steers)

\begin{tabular}{|c|c|c|c|c|c|c|c|c|}
\hline \multirow[t]{2}{*}{ Diet... } & \multicolumn{2}{|c|}{$\mathrm{U}$} & \multicolumn{2}{|c|}{ SCP } & \multicolumn{2}{|c|}{ MGM } & \multicolumn{2}{|c|}{ RSM } \\
\hline & Mean & $\mathrm{SE}$ & Mean & $\mathrm{SE}$ & Mean & $\mathrm{SE}$ & Mean & SE \\
\hline \multicolumn{9}{|c|}{ Microbial- $N$ yield (g/kg ADOM) } \\
\hline 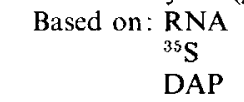 & $\begin{array}{l}29 \cdot 4 \\
31 \cdot 5 \\
26 \cdot 0\end{array}$ & $\begin{array}{l}2 \cdot 2 \\
2 \cdot 0 \\
4 \cdot 4\end{array}$ & $\begin{array}{l}32 \cdot 5 \\
29 \cdot 3 \\
21 \cdot 9\end{array}$ & $\begin{array}{l}3 \cdot 8 \\
2 \cdot 0 \\
1.9\end{array}$ & $\begin{array}{l}25 \cdot 1 \\
24 \cdot 7 \\
19 \cdot 1\end{array}$ & $\begin{array}{l}3 \cdot 2 \\
0 \cdot 9 \\
3 \cdot 3\end{array}$ & $\begin{array}{l}30 \cdot 5 \\
32 \cdot 0 \\
19 \cdot 8\end{array}$ & $\begin{array}{l}2 \cdot 8 \\
2 \cdot 4 \\
1 \cdot 9\end{array}$ \\
\hline \multicolumn{9}{|c|}{ Microbial- $\mathrm{N}$ yield $(\mathrm{g} / \mathrm{kg}$ TDOM $) \dagger$} \\
\hline $\begin{array}{r}\text { Based on: RNA } \\
{ }^{35} \text { S } \\
\text { DAP }\end{array}$ & $\begin{array}{l}21 \cdot 8 \\
22 \cdot 5 \\
19 \cdot 2\end{array}$ & $\begin{array}{l}1 \cdot 6 \\
0 \cdot 6 \\
3 \cdot 2\end{array}$ & $\begin{array}{l}24 \cdot 2 \\
21 \cdot 9 \\
16 \cdot 3\end{array}$ & $\begin{array}{l}2 \cdot 5 \\
1 \cdot 2 \\
1 \cdot 2\end{array}$ & $\begin{array}{l}19 \cdot 6 \\
19 \cdot 2 \\
14 \cdot 9\end{array}$ & $\begin{array}{l}2 \cdot 5 \\
0 \cdot 5 \\
2 \cdot 6\end{array}$ & $\begin{array}{l}22 \cdot 3 \\
23 \cdot 3 \\
14 \cdot 5\end{array}$ & $\begin{array}{l}2 \cdot 0 \\
1 \cdot 3 \\
1 \cdot 4\end{array}$ \\
\hline \multicolumn{9}{|c|}{$\begin{array}{l}\text { Microbial- } \mathrm{N} \text { yield }(\mathrm{g} / \mathrm{kg} \text { carbohydrate } \\
\text { fermented in the rumen) }\end{array}$} \\
\hline $\begin{aligned} \text { Based on: RNA } & \begin{aligned}{ }^{35} \mathrm{~S} \\
\text { DAP }\end{aligned}\end{aligned}$ & $\begin{array}{l}27 \cdot 6 \\
28 \cdot 6 \\
24 \cdot 2\end{array}$ & $\begin{array}{l}2 \cdot 4 \\
1 \cdot 4 \\
4 \cdot 3\end{array}$ & $\begin{array}{l}32 \cdot 8 \\
29 \cdot 7 \\
22 \cdot 2\end{array}$ & $\begin{array}{l}4 \cdot 4 \\
2 \cdot 1 \\
1 \cdot 9\end{array}$ & $\begin{array}{l}24 \cdot 3 \\
24 \cdot 2 \\
18 \cdot 4\end{array}$ & $\begin{array}{l}2 \cdot 9 \\
1 \cdot 8 \\
3 \cdot 3\end{array}$ & $\begin{array}{l}31 \cdot 9 \\
33 \cdot 3 \\
20 \cdot 9\end{array}$ & $\begin{array}{l}4 \cdot 7 \\
2 \cdot 3 \\
3 \cdot 4\end{array}$ \\
\hline
\end{tabular}

U, Straw + barley + urea + casein; SCP, straw + barley + urea + casein + single-cell protein; MGM, straw + barley + urea + casein + maize gluten meal; RSM, straw + barley + urea + casein + rapeseed meal; DAP, $\alpha, \epsilon-$ diaminopimelic acid.

* For details, see Table 1.

$\dagger$ Corrected for microbial OM contribution at the abomasum.

Estimates of total feed- $\mathrm{N}$ degradabilities calculated without correction for an $\mathrm{EN}$ contribution were $7 \cdot 5,6.6$ and $8.8 \%$ units less than the corrected values shown derived from ${ }^{35} \mathrm{~S}$, RNA and DAP respectively and the differences were all significant $(P<0.001)$. Uncorrected estimates of the basal-components (straw + barley) $\mathrm{N}$ degradability were $0.593,0.545$ and 0.371 derived using ${ }^{35} \mathrm{~S}$, RNA and DAP respectively. These were all significantly lower $(P<0.001)$ than the corrected values shown. Protein supplement degradability values uncorrected for an EN contribution were very similar to the corrected values shown.

\section{Efficiency of microbial protein synthesis}

OM intakes and the proportions of OM apparently (ADOM) or truly (TDOM) digested between mouth and abomasum are shown in Table 5. There were no significant differences in intakes or ADOM between diets. Values for TDOM on the other hand showed significantly greater digestion by paired $t$ test with diet RSM compared with diet U $(P<0 \cdot 10)$; diet SCP $(P<0.05)$ or diet MGM $(P<0.02)$. MN yields (Table 5), expressed in terms of ADOM were not significantly different when derived using either RNA or DAP as microbial marker. With ${ }^{35} \mathrm{~S}, \mathrm{MN}$ yields were significantly lower for diet MGM compared with diets $\mathrm{U}$ and SCP $(P<0.10)$ or diet RSM $(P<0.05)$. When efficiencies were expressed in terms of TDOM, no significant differences were found between diets using either RNA or DAP as microbial markers and with ${ }^{35} \mathrm{~S}$ the only significant difference found $(P<0.05)$ was a lower efficiency with diet RSM compared with diet MGM. Table 5 also shows the efficiencies of MN synthesis in terms of carbohydrate fermented in the rumen. Values obtained for diet MGM were found to be significantly lower than those obtained for diets SCP and RSM with either RNA or ${ }^{35} \mathrm{~S}$ as microbial markers. No other significant differences were found. Efficiencies derived using DAP as microbial marker were 
Table 7. Daily intakes ( $\mathrm{g} / \mathrm{d})$, abomasal flows ( $\mathrm{g} / \mathrm{d}$ ) and apparent rumen digestibilities ( $\mathrm{g} / \mathrm{g}$ intake) of the major dietary carbohydrates together with mean amounts of organic matter $(O M)$ consumed $(\mathrm{kg} / \mathrm{d})$, flowing to the abomasum $(\mathrm{kg} / \mathrm{d})$ and the proportions of $O M$ intake apparently (ADOM) and truly (TDOM) digested between mouth and abomasum of steers given diets containing different protein supplements*

(Results are mean values with their standard errors for four steers)

\begin{tabular}{|c|c|c|c|c|c|c|c|c|}
\hline \multirow{2}{*}{$\begin{array}{l}\text { Diet... } \\
\text { Component }\end{array}$} & \multicolumn{2}{|c|}{$\mathrm{U}$} & \multicolumn{2}{|c|}{$\mathrm{SCP}$} & \multicolumn{2}{|c|}{ MGM } & \multicolumn{2}{|c|}{ RSM } \\
\hline & Mean & $\mathrm{SE}$ & Mean & SE & Mean & SE & Mean & $\mathrm{SE}$ \\
\hline \multicolumn{9}{|l|}{$\mathrm{OM}$} \\
\hline Intake & $2 \cdot 68$ & $0 \cdot 12$ & 2.65 & $0 \cdot 13$ & 2.66 & $0 \cdot 14$ & $2 \cdot 77$ & $0 \cdot 14$ \\
\hline Flow at abomasum & $1 \cdot 27$ & $0 \cdot 08$ & $1 \cdot 29$ & 0.02 & $1 \cdot 28$ & 0.09 & $1 \cdot 29$ & 0.08 \\
\hline ADOM & 0.53 & $0 \cdot 019$ & 0.52 & 0.029 & 0.52 & 0.022 & 0.54 & 0.03 \\
\hline TDOM + & 0.71 & 0.028 & $0 \cdot 69$ & $0 \cdot 017$ & 0.67 & 0.018 & 0.73 & 0.018 \\
\hline \multicolumn{9}{|l|}{ Galactose } \\
\hline Intake & 38 & $1 \cdot 2$ & 39 & $1 \cdot 2$ & 41 & $1 \cdot 8$ & 59 & 1.9 \\
\hline Flow at abomasum & 10 & 1.6 & 9 & $2 \cdot 4$ & 8 & 0.5 & 10 & 0.3 \\
\hline $\begin{array}{l}\text { Proportion digested } \\
\text { in the rumen }\end{array}$ & 0.73 & $0 \cdot 04$ & $0 \cdot 77$ & $0 \cdot 06$ & $0 \cdot 80$ & 0.02 & 0.83 & 0.01 \\
\hline \multicolumn{9}{|l|}{ Arabinose } \\
\hline Intake & 71 & $2 \cdot 2$ & 71 & $2 \cdot 2$ & 73 & $2 \cdot 3$ & 107 & $3 \cdot 4$ \\
\hline Flow at abomasum & 23 & 0.6 & 21 & $2 \cdot 5$ & 16 & $0 \cdot 9$ & 20 & 0.9 \\
\hline $\begin{array}{l}\text { Proportion digested } \\
\text { in the rumen }\end{array}$ & 0.68 & 0.00 & $0 \cdot 70$ & 0.04 & $0 \cdot 78$ & 0.01 & 0.81 & 0.01 \\
\hline \multicolumn{9}{|l|}{ Xylose } \\
\hline Intake & 272 & $8 \cdot 4$ & 272 & $8 \cdot 4$ & 274 & $8 \cdot 5$ & 285 & $8 \cdot 8$ \\
\hline Flow at abomasum & 101 & $3 \cdot 7$ & 89 & $5 \cdot 9$ & 66 & $1 \cdot 7$ & 60 & $2 \cdot 3$ \\
\hline $\begin{array}{l}\text { Proportion digested } \\
\text { in the rumen }\end{array}$ & 0.63 & 0.09 & $0 \cdot 67$ & $0 \cdot 02$ & $0 \cdot 76$ & $0 \cdot 01$ & 0.79 & 0.01 \\
\hline \multicolumn{9}{|l|}{ Cellulose-glucose } \\
\hline Intake & 544 & $16 \cdot 7$ & 544 & $17 \cdot 1$ & 547 & $16 \cdot 8$ & 593 & $18 \cdot 3$ \\
\hline Flow at abomasum & 210 & $15 \cdot 0$ & 182 & 7.6 & 138 & $5 \cdot 2$ & 145 & $15 \cdot 0$ \\
\hline $\begin{array}{l}\text { Proportion digested } \\
\text { in the rumen }\end{array}$ & 0.61 & $0 \cdot 02$ & 0.67 & $0 \cdot 02$ & 0.75 & $0 \cdot 00$ & 0.76 & 0.02 \\
\hline \multicolumn{9}{|l|}{ Starch-glucose } \\
\hline Intake & 1002 & $31 \cdot 3$ & 779 & $24 \cdot 4$ & 783 & $25 \cdot 3$ & 673 & $21 \cdot 6$ \\
\hline Flow at abomasum & 101 & $10 \cdot 5$ & 76 & $1 \cdot 9$ & 79 & $6 \cdot 0$ & 68 & $11 \cdot 6$ \\
\hline $\begin{array}{l}\text { Proportion digested } \\
\text { in the rumen }\end{array}$ & 0.90 & 0.01 & 0.90 & 0.00 & 0.90 & 0.01 & 0.90 & 0.02 \\
\hline
\end{tabular}

$\mathrm{U}$, Barley + straw + urea + casein; SCP, barley + straw + urea + casein + single-cell protein; MGM, barley + straw + urea + casein + maize-gluten meal; RSM, barley + straw + urea + casein + rapeseed meal.

+ Corrected for microbial OM flow at the abomasum.

* For details, see Table 1.

significantly $(P<0.001)$ lower than those obtained with either ${ }^{35} \mathrm{~S}$ or RNA however they were expressed.

\section{Carbohydrate disappearance between mouth and abomasum}

The carbohydrate composition of the different feed components are given in Table 6 . Appreciable amounts of starch-glucose were found in the maize-gluten meal $(184 \mathrm{~g} / \mathrm{kg}$ DM) and considerable amounts of structural sugars in the rapeseed meal (about $200 \mathrm{~g} / \mathrm{kg}$ DM). Daily intakes, abomasal flows and apparent rumen digestibilities of the main dietary carbohydrates are presented in Table 7 . Of the other minor sugars measured but not 
reported in detail, intakes of mannose were similar with all diets at about $7.5 \mathrm{~g} / \mathrm{d}$, of which approximately 0.60 disappeared between mouth and abomasum. Ribose intakes of about $12 \mathrm{~g} / \mathrm{d}$ were found with diet SCP and about $7 \mathrm{~g} / \mathrm{d}$ with the other diets, all of which had an apparent digestibility of about 0.60 . Intakes of rhamnose with all diets were less than $1 \mathrm{~g} / \mathrm{d}$ and there were net gains of $4-6 \mathrm{~g} / \mathrm{d}$ between mouth and abomasum. Intakes of galactose, arabinose, xylose and cellulose-glucose were similar between diets, U, SCP and MGM but were all higher with diet RSM. There were no significant differences in abomasal flows of galactose but rumen digestibility was greater with the protein-supplemented diets compared with diet $\mathrm{U}$, but the difference was only significant for diet RSM. Flows of arabinose at the abomasum of steers receiving diet MGM were lower than those with the other diets. Rumen digestibilities were significantly greater $(P<0.05)$ with diets RSM and MGM compared with diets U or SCP. There were significant differences in the amounts of xylose and cellulose passing the abomasum with different diets. Diet RSM supported the highest rumen degradabilities of xylose and cellulose and these were significantly greater $(P<0.05)$ than those obtained with either diets U or SCP. There were no significant differences between diets MGM or RSM but digestibilities with diet MGM were significantly greater than those with diets U or SCP.

There were expected differences between starch intake of the basal diet compared with the other diets as a result of replacement of some tapioca with protein supplement and this was reflected in abomasal flows. However, mouth to abomasal digestibilities of starch were similar with all diets.

\section{DISCUSSION}

The use of chronically fistulated animals is the most realistic means of studying synthetic and degradative processes in the rumen under conditions approaching those found in practice. These types of experiment are extremely intensive and very difficult to perform with both physical and practical limitations on the number of animals which can be used in any one experiment. A Latin square design was deemed to be the best choice in the present experiments because of the small numbers of animals used. The limitations of this design with respect to degrees of freedom, different randomizations, etc. are fully recognized.

In the present experiments, no urea was detected in any abomasal digesta. It seems certain also that the casein in the basal diet (diet $\mathrm{U}$ ) would have been effectively degraded before digesta left the rumen (McDonald, 1954; Williams \& Smith, 1976), although it would transiently have provided amino acids and peptides in addition to those coming from microbial turnover. Thus it is reasonable to assume that virtually all the nonmicrobial NAN entering the duodenum of animals receiving diet $U$ came from straw pellets and barley plus endogenous material and that the NAN additional to this amount passing the duodenum of animals receiving protein-supplemented diets was of supplement origin. Calculation in this way of undegraded supplement $\mathrm{N}$ is not dependent on any estimate of EN although it does assume that this remains constant between diets. On the other hand degradability values for whole diets calculated simply by deducting an estimate of $\mathrm{MN}$ from the total NAN flow at the duodenum or abomasum are based on an assumption that $\mathrm{EN}$ is negligible. This is generally recognized to be untrue but correction depends on using an assessed value for EN. In the values given in Table 4 we have assumed a value of 32 $\mathrm{mg} / \mathrm{kg}$ live weight per d (Ørskov \& MacLeod, 1983) and, taking this into account, EN had a substantial effect on calculated degradability; on average it increased values for whole diets by $7 \%$ points and values for residual basal constituents by about $15 \%$ points. Other experiments have indicated that EN for cattle is variable and may be greater than this (Ørskov et al. 1986) and other workers have sometimes calculated degradability values 
using assumed EN values more than twice those used in Table 4 (Amaning-Kwarteng et al. 1986). It appears that values calculated by this method should be viewed with caution.

Problems in the estimation of $\mathrm{MN}$ flows by different procedures and their use in deriving protein degradabilities have been pointed out (MacRae \& Reeds, 1980). Our results using DAP as a marker were always significantly lower than those derived using the other markers (Table 4). This was presumably mainly a result of protozoal- $\mathrm{N}$ contribution at the abomasum. Values derived using RNA as microbial marker were very similar to those using ${ }^{35} \mathrm{~S}$ except for diet SCP. This was probably because single-cell protein had a very high RNA content (RNA-N:TN was 0.13) and some of this RNA survived the rumen to be attributed to rumen microbial RNA. This would have resulted in an overestimation of single-cell protein degradability.

A number of workers have reported degradability values for maize-gluten meal. Thus Stern et al. (1983) used lactating dairy cows which were given, in four meals/d, a series of diets composed of approximately equal proportions of concentrates and roughages to which various levels of maize-gluten meal had been added. Degradability of the maize-gluten meal was calculated by regression of duodenal amino acids on amino acid intake and showed that $43 \%$ of the maize gluten meal was degraded in the rumen. Other experiments with growing steers receiving roughage-concentrate diets $(40: 60, \mathrm{w} / \mathrm{w})$ supplemented with maize-gluten meal and using RNA to measure $M N$ indicated the percentage of maize-gluten meal intake degraded in the rumen to be 39 (Zinn et al. 1981), while a recent study with steers receiving roughage-concentrate $(20: 80, \mathrm{w} / \mathrm{w})$ diets (Garrett et al. 1987) showed a value of 58. Our own value for the percentage of maize-gluten meal degraded in the rumen of 51 was consistent with these estimates.

Very little information obtained in vivo appears to exist concerning the degradability in the rumen of single-cell protein or rapeseed meal. Hagemeister \& Kaufmann (1974) in experiments with milking cows obtained degradability values of 60 and $58 \%$ for rapeseed meal and single-cell protein respectively. However, these values were derived using DAP as a 'microbial' marker and were from animals in which duodenal digesta were collected posterior to the entry of the bile and pancreatic ducts, so that EN estimates would have been elevated. Both these factors would have resulted in underestimation of dietary protein degradability. More recently Rooke et al. (1983), in experiments with heifers receiving silage-based diets given twice daily and using ${ }^{35} \mathrm{~S}$ as microbial marker, obtained a mean degradability value for rapeseed-meal-supplement protein of $77 \%$. The only other information available for these supplements appears to be that based on the 'in rumen' porous synthetic fibre (psf) bag method. For single-cell protein, predicted values ranged from 46 to $72 \%$ depending on the liquid fractional outflow rate assumed (Teller et al. 1985). A number of studies have been made for rapeseed meal using the psf bag method and have given values ranging from 68 to $87 \%$ (Agricultural Research Council, 1984; Madsen \& Hvelplund, 1985; Ørskov et al. 1981) with values again being markedly influenced by assumed outflow rates (Ørskov et al. 1981).

Thus, while our ${ }^{35} \mathrm{~S}$-based degradability value for single-cell protein of $73 \%$ is not inconsistent with the small amount of published information, our value of $98 \%$ for rapeseed meal is very high. The reason for this is not clear, particularly as the liquid outflow rates for rapeseed meal in the present experiments were relatively high, about $0 \cdot 16 / \mathrm{h}$. It seems unlikely that the frequent feeding used in the present experiments could have been responsible (Robinson \& Sniffen, 1985) and presumably the high degradability was simply a characteristic of the particular sample of rapeseed meal used. Certainly rapeseed meal solubility can vary considerably with preparation procedure (Laycock \& Miller, 1981).

The mean efficiency of microbial protein synthesis obtained in these experiments of approximately $30 \mathrm{~g} \mathrm{MN} \mathrm{kg} \mathrm{ADOM} \mathrm{(rumen;} \mathrm{derived} \mathrm{from} \mathrm{RNA} \mathrm{and}{ }^{35} \mathrm{~S}$ ) was similar to 
that reported as a mean for a wide variety of diets (Agricultural Research Council, 1980) and found in a number of more recent studies (e.g. Meyer et al. 1986). There appeared to be a tendency for reduced efficiency with diet MGM as reported also by Garrett et al. (1987), but this was not generally significant. Efficiency values in the present work were appreciably higher than those (14-20) reported previously for steers receiving similar diets based on ground and pelleted alkali-treated straw and rolled barley with a variety of protein supplements (McAllan et al. 1986). It was suggested for the earlier work that the low efficiencies observed may have been causally related to the inclusion of sodium hydroxide-treated straw in the diets, but this was not supported by the present findings. The apparent conflict may have been because in the present experiments diets were given eight times daily compared with only twice daily in the earlier work and it has been shown that increased frequency of feeding may result in increased efficiency (McAllan et al. 1987; Tamminga, 1979, 1982). Although, as for the values quoted previously, ADOM (rumen) is commonly used as a measure of energy supply when assessing the efficiency of microbial protein synthesis (e.g. Agricultural Research Council, 1980, 1984), some workers have suggested that carbohydrate digestion in the rumen might form a more appropriate basis for the calculation (Madsen, 1985). The results given in Table 4 indicated, however, that estimates of ADOM (rumen) corresponded closely to those of total carbohydrate disappearance. This would not necessarily apply under all conditions but the finding suggests that for commonly used ruminant diets it would make little practical difference in a feeding system which of these bases were used.

Digestibility values between mouth and abomasum obtained for fibre fractions of the diets used in the present experiments $(0.63-0.83$ for hemicellulose sugars and $0 \cdot 61-0.76$ for cellulose) were broadly in the range found in earlier experiments with growing steers given diets based on alkali-treated straw and barley and supplemented with protein (McAllan \& Griffith, 1987). A number of previous studies both in vitro (Vestergaard-Thomsen, 1985) and in vivo (McAllan \& Smith, $1983 b$; McAllan \& Griffith, 1987) have demonstrated that fibre digestion in the rumen varied with the kind, as well as the amount, of dietary protein and this was shown also in the present work. In the earlier studies diets containing a rapidly degraded dietary $\mathbf{N}$ supplement generally supported less fibre digestion than those containing more resistant dietary protein, and it was postulated that one reason for the difference may have been that a slow release of peptides or amino acids was beneficial to cellulolytic and hemicellulolytic activity.

This hypothesis received support in the present study when diet SCP was compared with diets $U$ and MGM which contained more and less rapidly degradable 'protein ' respectively. Xylose, arabinose and $\beta$-linked (cellulose) glucose rumen digestibilities were all ranked in the order diets MGM > SCP > U with many of the differences being significant (Table 7). The hypothesis is not, however, supported when diet RSM is considered. This supplement was found to be degraded as completely as the 'protein' in diet $U$ and yet, in diets containing it, fibre digestion was little different to that seen with diets containing the resistant maize-gluten-meal supplement. Thus the results provide confirmation that different protein sources facilitate fibre digestion to different extents, but go against the ideas either that this was due to differences in $\mathrm{NH}_{3}$ release $\left(\mathrm{NH}_{3}\right.$ concentration was highest with diet $\mathrm{U}$ ) or simply to differences in degradability. However, it has been shown in vitro (Vestergaard-Thomsen, 1985) that cellulolytic microbes may need a supply of long-chain peptides for optimal growth and differences between protein sources in sustaining fibre digestion may reflect differences in the pattern of breakdown of these proteins in the rumen. 
The authors thank Miss P. E. Lewis and Mr E. S. Griffith for skilled technical assistance and Dr S. Unsworth of J. Bibby Agriculture Limited for his kind gift of the rapeseed meal. This work was financed through the Agricultural and Food Research Council as part of a commission from the Ministry of Agriculture, Fisheries and Food.

\section{REFERENCES}

Agricultural Research Council (1980). The Nutrient Requirements of Ruminant Livestock. Slough : Commonwealth Agricultural Bureaux.

Agricultural Research Council (1984). The Nutrient Requirements of Ruminant Livestock, Supplement no. 1. Slough: Commonwealth Agricultural Bureaux.

Amaning-Kwarteng, K., Kellaway, R. C., Leibholz, J. \& Kirby, A. C. (1986). British Journal of Nutrition 55 , $387-398$.

Cochran, J. W. \& Cox, G. M. (1962). Experimental Designs, 2nd ed., p. 50. New York: Wiley.

Cockburn, J. C. \& Williams, A. P. (1984). British Journal of Nutrition 51, 111-132.

Garrett, J. E., Goodrich, R. D., Meiske, J. C. \& Stern, M. D. (1987). Journal of Animal Science 64, $1801-1812$.

Hagemeister, H. \& Kaufmann, W. (1974). Kieler Milchwirtschaftliche Forschungsberichte 26, 199-204.

Kaufmann, W. (1977). In Protein Metabolism and Nutrition, European Association of Animal Production, no. 22, pp. 130-132 [S. Tamminga, Conference Secretary]. Wageningen, The Netherlands: Centre for Agricultural Publishing and Documentation.

Laycock, K. A. \& Miller, E. L. (1981). Proceedings of the Nutrition Society 40, 103A.

McAllan, A. B. \& Griffith, E. S. (1987). Animal Feed Science and Technology 17, 65-73.

McAllan, A. B., Lewis, P. L. \& Griffith, E. S. (1987). Archiv für Tierernährung 37, 791-803.

McAllan, A. B. \& Smith, R. H. (1969). British Journal of Nutrition 23, 671-681.

McAllan, A. B. \& Smith, R. H. (1974). British Journal of Nutrition 31, 77-88.

McAllan, A. B. \& Smith, R. H. (1983a). British Journal of Nutrition 49, 119-127.

McAllan, A. B. \& Smith, R. H. (1983b). British Journal of Nutrition 50, 445-454.

McAllan, A. B., Williams, A. P., Cockburn, J. E., Griffith, E. S., Lewis, P. E. \& Smith, R. H. (I986). Archiv für Tierenährung 4/5, 409-418.

McDonald, I. W. (1954). Biochemical Journal 56, 120-125.

MacRae, J. C. \& Reeds, P. J. (1980). In Protein Deposition in Animals, pp. 225-249 [P. J. Buttery and D. B. Lindsay, editors]. London: Butterworths.

Madsen, J. (1985). Acta Agriculturae Scandinavica 25, Suppl., 9-20.

Madsen, J. \& Hvelplund, T. (1985). Acta Agriculturae Scandinavica 25, Suppl., 101-124.

Mathers, J. C. \& Miller, E. L. (1980). British Journal of Nutrition 43, 503-514.

Merry, R. J. (1980). The use of dietary non-protein nitrogen compounds by the ruminant with particular emphasis on the glycosyl ureides. Ph.D. thesis, University of Reading.

Meyer, J. H. F., van der Walt, S. I. \& Schwartz, H. M. (1986). Journal of Animal Science 62, 509-520.

Ministry of Agriculture, Fisheries and Food (1975). Energy Allowances and Feeding Systems for Ruminants. Technical Bulletin no. 33. London: H.M. Stationery Office.

Ørskov, E. R., Hughes-Jones, M. \& McDonald, I. (1981). In Recent Developments in Ruminant Nutrition, pp. 17-36 [W. H. Haresign and D. J. A. Cole, editors]. London: Butterworths.

Orskov, E. R. \& MacLeod, N. A. (1983). Proceedings of the Nutrition Society 42, 61A.

Ørskov, E. R., MacLeod, N. A. \& Kyle, D. J. (1986). British Journal of Nutrition 56, 241-248.

Robinson, P. H. \& Sniffen, C. J. (1985). Journal of Dairy Science 68, 857-867.

Rooke, J. A., Brookes, I. M. \& Armstrong, D. G. (1983). Journal of Agricultural Science, Cambridge 100, 329-342.

Smith, R. H. \& McAllan, A. B. (1970). British Journal of Nutrition 24, 545-556.

Smith, R. H. \& McAllan, A. B. (1971). British Journal of Nutrition 25, 181-190.

Smith, R. H. \& McAllan, A. B. (1974). British Journat of Nutrition 31, $27-34$.

Smith, R. H., McAllan, A. B., Hewitt, D. \& Lewis, P. E. (1978). Journal of Agricultural Science, Cambridge 90, $557-568$.

Snedecor, G. W. \& Cochran, W. G. (1972). Statistical Methods, pp. 91-97. Ames, Iowa: Iowa State University Press.

Stern, M. D., Rode, L. M., Prange, R. W., Stauffacher, R. H. \& Satter, L. D. (1983). Journal of Animal Science 56, 194-205.

Tamminga, S. (1979). Journal of Animal Science 49, 1615-1630.

Tamminga, S. (1982). Nitrogen and Amino Acid Metabolism in Dairy Cows, pp. 87-91. Wageningen: PUDOC.

Technicon Instruments Corporation (1967). Methodology Sheet NIC. New York: Technicon Instruments Corporation.

Teller, E., Godeau, J.-M., Van Nevel, C. J. \& Demeyer, D. 1. (1985). Zeitschrift für Tierphysiologie, Tierernährung und Futtermittelkunde 54, 121-130.

Verite, R., Journet, M. \& Jarrige, R. (1979). Livestock Production Science 6, 349-367. 
Vestergaard-Thomsen, K. (1985). Acta Agriculturae Scandinavia 25, Suppl. 125-131.

Warner, A. C. 1. (1962). Journal of General Microbiology 28, 119-128.

Williams, A. P. (1986). Research and Development in Agriculture 3, 1-5.

Williams, A. P. \& Smith, R. H. (1974). British Journal of Nutrition 32, 421-433.

Williams, A. P. \& Smith, R. H. (1976). British Journal of Nutrition 36, 199-209.

Zinn, R. A., Bull, L. S. \& Hemken, R. W. (1981). Journal of Animal Science 52, 857-866. 